\title{
Flood hazard vulnerability for settlements of Turkey's province of Edirne, using ASTER DEM data and Landsat-7 ETM+ image data
}

\author{
Ali Can Demirkesen ${ }^{1}$ \\ Received: 4 March 2015 / Accepted: 1 December 2015 / Published online: 10 March 2016 \\ (C) Saudi Society for Geosciences 2016
}

\begin{abstract}
While Turkey's province of Edirne represents one of the country's most significant cultural heritage areas because it lies in the basins of the Meric and Ergene rivers, this very valuable region is highly susceptible to flooding during heavy rain falls. It becomes particularly vulnerable when neighboring Bulgaria responds to its own threats of heavy rain or snowfall by opening its floodgates of its dams on the River Meric, which flows through the Edirne province. Therefore, for years, the Edirne province has experienced severe floods that are eroding its fertile alluvial agricultural floodplains. An environmental plan based on a determination of the vulnerability levels of the province's flood hazard risk areas is required if action is taken to alleviate this problem. The objective of this study is to acquire geo-information from the remotely sensed data and to interpret the flood hazard risk levels of the area's settlements and agricultural floodplains. In this study, the spatial distribution of the flood hazard risk areas in the Edirne province is determined using not only the Advanced Space-Borne Thermal Emission and Reflection Radiometer digital elevation model data of the Edirne province to create maps that illustrate the digital terrain model and the 3D fly-through dynamic model of the study region but also the Landsat-7 Enhanced Thematic Mapper Plus multi-spectral image data set to create land use and land cover types of the study region. The maps exhibit landform characteristics, floodplain topography, and stream drainages. Analysis and interpretation of the maps demonstrate that the areas most susceptible to flooding are Enez, which lies at the northern coastal area of
\end{abstract}

Ali Can Demirkesen

ademirkesen@yahoo.com

1 Department of City and Regional Planning, Izmir Institute of Technology, Izmir, Turkey the Aegean Sea and agricultural areas, and the settlements on the Meric River floodplains of Ipsala, Meric, Edirne, and Uzunkopru, listed in decreasing order, respectively.

Keywords Flood hazard vulnerability · Remote sensing · Geographic Information System · Edirne, Turkey

\section{Introduction}

The Edirne province, one of Turkey's most significant cultural heritage sites, is located in a region of high-risk flooding in instances of heavy rainfalls and/or melting snow. Flood records in the Edirne province show that since 1940 the area has experienced 50 floods that resulted in loss of lives and property (MGM 2013). These disasters highlight the study region's high susceptibility to flooding. For years, the severe flooding in the Edirne province has been exacerbated by Bulgaria's opening of the floodgates of its dams on the River Meric, which flows through the Edirne province to the south before discharging its waters into the northern Aegean Sea. When the River Meric overflows its banks after heavy rain and/or melting snow, the resulting floods not only inundate social facilities, such as bridges, roads, streets, houses, workplaces, restaurants, cafes, and animal shelters located on near the river but also cause loss of lives. The first area subjected to the disastrous flooding is the administrative city of Edirne, located in the junction of the Meric, Arda, and Tunca rivers. The floods next affect the town of Ipsala and its low-lying agricultural floodplains located in the junction of the Meric and Ergene rivers. Finally, it affects Enez, before finally discharging into the northern Aegean Sea.

Many local governments have also been recently reporting that in times of heavy rainfall, the hazards of river floods have threatened those settlements built in low-lying agricultural 
plain and/or valleys. This heavy rainfall and erosion is having an adverse impact on the economy and the country's ecosystems (Schanze et al. 2006).

One of the most important and commonly shared issues faced by policy makers is the management of flood disasters that have the potential of imposing both social and economic hardships. Therefore, policy makers need analysis tools and models to improve their decision-making processes so as to minimize the adverse effects of those flood disasters that are meteorology-based due to heavy rainfall caused by climate changes (Brivio et al. 2002; Schanze et al. 2006; Kim et al. 2011; Kandilioti and Makropoulos 2012).

While historical records of the Edirne province show that the region's population has always lived under considerable threat of flooding, a literature review reveals a paucity of analyses of the geological characteristics of the Edirne province in terms of its considerable flood hazard risk. Despite the lack of studies on Edirne per se, however, the literature does reveal a large number of research into similar concerns (Brivio et al. 2002; Wang et al. 2002; Van der Sande et al. 2003; Sanyal and Lu 2004; Schanze et al. 2006; Meyer et al. 2009). Some previous studies have investigated flood hazards similar to those discussed in our study. Among those are investigations of the effects of the Digital Terrain Model (DTM), landscape characteristics, and the topography-based watershed model. For example, Wang et al. (2002) used Landsat Thematic Mapper and Digital Elevation Model (DEM) data to map the extent of flooding in coastal flood plains. These authors described an efficient and reliable method for mapping flood areas in coastal flood plains and modeling inundation using the DEM data. Van der Sande et al. (2003) looked at flood risk and flood damage assessment. They created land cover maps from highresolution satellite imagery, the Ikonos, to assist the flood risk and flood damage assessment. Sanyal and Lu (2004) and Schanze et al. (2006) studied the hazards, vulnerability, and mitigation measures for flood risk management. Brivio et al. (2002), Meyer et al. (2009), Ho et al. (2010), Hoque et al. (2011), and Kandilioti and Makropoulos (2012) studied flood monitoring and mapping using remote sensing (RS) integrated with Geographic Information System (GIS).

The objectives of this study are to both acquire geoinformation about the Edirne province of Turkey using the remotely sensed data and to describe the flood hazard risk levels to settlements and agricultural areas in the study region. The main data sources are the Advanced Space-Borne Thermal Emission and Reflection Radiometer (ASTER) DEM data and the Landsat-7 ETM+ multi-spectral image data set of the study region. Existing landscape characteristics are also analyzed for the flood hazard vulnerability. By quantifying and analyzing the DTM (Wilson and Gallant 2000) and hydrological features of the Edirne province, geoinformation is acquired to help (1) control and extend the existing flood hazard precaution and prevention measures, (2) evaluate the suitability and flexibility of current regional development plan strategies in relation to the flood hazards, and (3) assist in decision-making regarding future land planning and efficient flood management in the study area. In this study, the major river drainages and water flow accumulation areas that indicate flood-prone zones are also investigated and analyzed in terms of flood hazards.

Our results/findings and the maps created in this study significantly contribute to environmental planning in the Edirne province, where the river flood hazards are important concern. This study also demonstrates the analysis of digital terrain, elevation classification, extraction of river drainages, and describing water accumulation areas with land use/land cover types using the RS integrated with the GIS.

Developing high technologies in the RS and GIS have eased data collection and processes for the flood hazard risk interpretation of the settlements. By employing the RS techniques integrated with the GIS, we not only analyze the DTM and the landscape characteristics but also extract and analyze the stream drainages in terms of the flood hazard.

Thus, the objectives of this study are the following: (1) firstly, to obtain geo-information about the study region by generating the DTM, exhibiting the landforms, floodplain topography, and watersheds; (2) secondly, to determine spatial distributions of the settlements having the river flood hazard risks overlaid with the land use/land cover (LULC) types; and (3) finally, to contribute to decision-making on any future environmental planning, efficient flood management, and to preserve settlements and ecosystems.

\section{Study region}

The Edirne province is roughly located at $26^{\circ}-28^{\circ} \mathrm{E}$ meridians and $40^{\circ}-42^{\circ} \mathrm{N}$ parallels (Fig. 1). While the total study region is $21,260 \mathrm{~km}^{2}$, according to 2011 statistics (TUIK 2013), the province of Edirne has an area of $6276 \mathrm{~km}^{2}$ and a population of about 400,000 . The Edirne province is surrounded by the provinces of Kirklareli and Tekirdag to the west, the country of Bulgaria to the north, Greece to the east, and the Aegean Sea to the south.

The study region has Mediterranean and Marmara climates with a mild winter and mean annual precipitation of about $850 \mathrm{~mm}$ and a hot summer. The heavy rainfall it generally receives in spring is the cause of its floods. Its average temperature is $5{ }^{\circ} \mathrm{C}$ in January and $25^{\circ} \mathrm{C}$ in July (Atalay 2008; Edirne Governorship 2013; MGM 2013). 


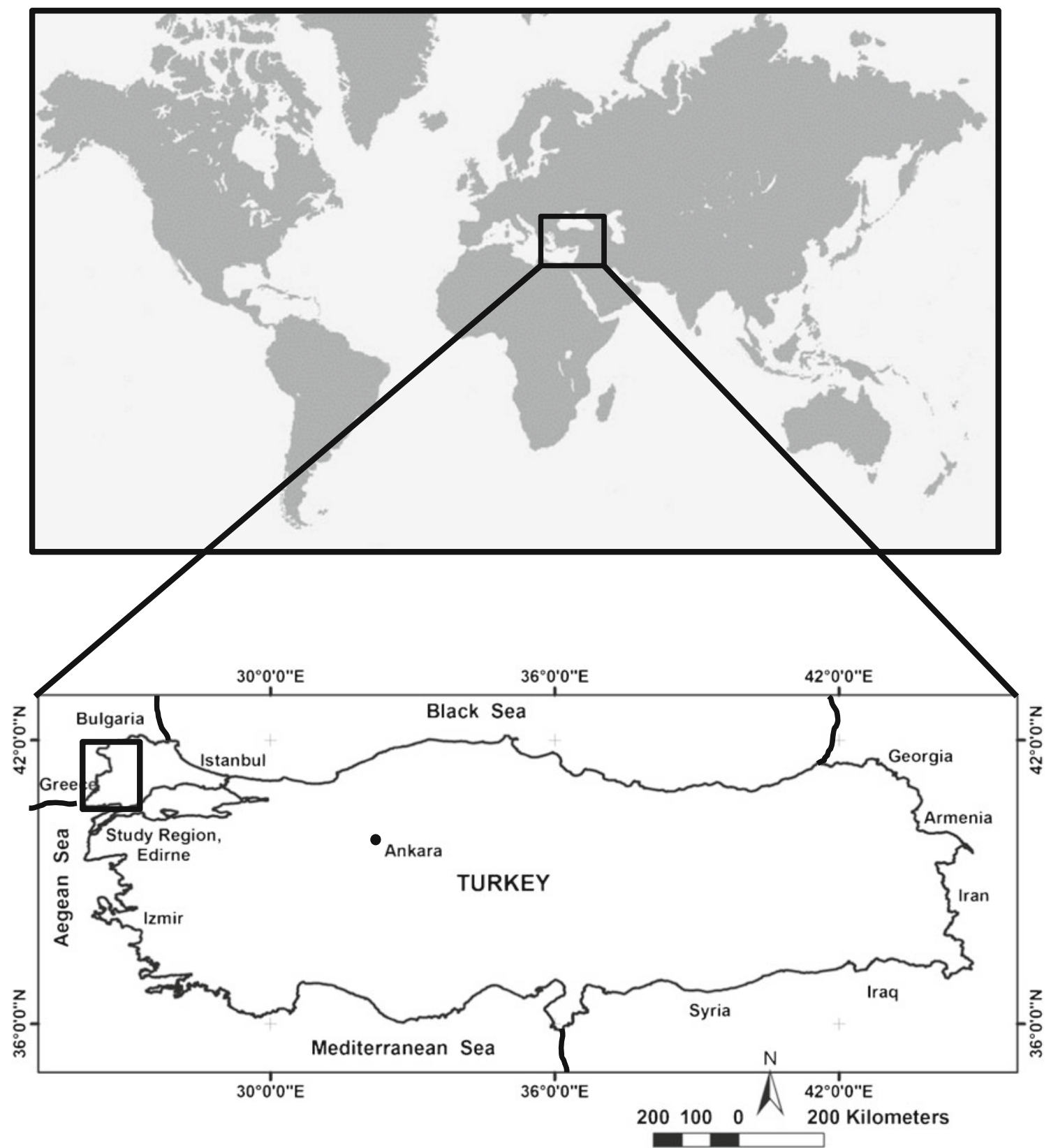

Fig. 1 Location of the Edirne province

The Edirne province is located in the greater region of Eastern Thrace (termed Trakya in Turkish) along the borders of Greece and Bulgaria. The Edirne province has nine administrative areas: the provincial seat of Edirne and the counties of Enez, Havsa, Ipsala, Kesan, Lalapasa, Meric, Suloglu, and Uzunkopru. The provincial seat of Edirne is a gateway city, connecting Turkey to Europe. It is settled on slopes and the fertile river flood plains formed by the junction of the three rivers: Meric, Tunca, and Arda. The River Meric (Maritza) originates in Bulgaria and flows through the border between the province of Edirne and Greece. The river discharges into the northern Aegean Sea at Enez. The Tunca and Arda rivers, both sub-tributaries of the River
Meric, flow from Bulgaria and meet the River Meric at the city of Edirne. The Edirne province also has a second major river called the Ergene which flows from Kirklareli before merging with the River Meric at Ipsala and then flowing to the Aegean Sea through Enez. The Meric and Ergene rivers merge in the Ergene basin, a water accumulation area that faces the threat of flood hazards. While the region does have a few hills and slopes, the province of Edirne does not have any high mountains within its borders and none of its hills surpasses $500 \mathrm{~m}$ in height. Most of the province consists of flat agricultural plains. The province is also largely deforested (Atalay 2008; Baykan 2004; GEODATA 2013). 


\section{Data}

\section{ASTER DEM data}

The ASTER DEM data were gained by means of an international joint project undertaken between the Ministry of Economy, Trade and Industry of Japan (METI) and the National Aeronautics and Space Administration (NASA). The ASTER, which is a space-borne earth-observing optical instrument, consists of an earth-observing sensor developed in Japan that is onboard the satellite Terra. Since its launch in December 1999, the sensor has continued to operate for more than 10 years in a stable manner. The sensor comprehensively captures spectral ranging from visible to thermal infrared (invisible to the human eye) and offers detailed information on earth surface conditions (e.g., vegetation, geological features) together with their distribution. The distribution of surface temperature can be observed by the thermal infrared sensor. These data support detailed studies of such phenomenon as the urban heat island effect. The ASTER elevation data are generated from a stereo-pair of images acquired with nadir and backward angles over the same area (ASTER GDEM 2013; ERSDAC 2013).

The ASTER elevation data in the geographic coordinate system, WGS84 datum, were obtained from the Consortium for Spatial Information, in the format of Geotiff as 32 bits. The ASTER mainly operates in the microwave wavelengths of electromagnetic spectrum and uses radar sensors for the collection of DEM data. The ASTER elevation data have the spatial resolution of $30 \mathrm{~m}$, with horizontal and vertical accuracies of 15 and $8 \mathrm{~m}$, respectively (San and Suzen 2005; ASTER GDEM 2013; ERSDAC 2013).

\section{Landsat-7 ETM+ multi-spectral image data}

Geometrically and radiometrically rectified Landsat-7 Enhanced Thematic Mapper Plus (ETM+) multi-spectral image data set of the study region was used for classification of LULC types. The Landsat-7 ETM+ image set dated 2 July 2000 and in geographic coordinates was obtained from the Global Land Cover Facility (GLCF), Earth Science Data Interface (ESDI) (GLCF 2013). The Landsat-7 ETM+ is a multispectral scanning radiometer carried onboard the Landsat satellite that provides a multi-spectral image data set from eight spectral bands. The spatial resolution is $30 \mathrm{~m}$ for the visible and near-infrared (bands 1-5 and 7). Resolution for the panchromatic (band 8) is $15 \mathrm{~m}$, and the thermal infrared (band 6) is $60 \mathrm{~m}$ (GLCF 2013).

\section{Maps and GIS layers}

Digital topographic and LULC map layers of the study region at the scale of 1:100,000 were obtained from the General
Command of Mapping (Turkish: Harita Genel Komutanliği, HGK) (HGK 2013). These digital maps include a few numbers of the GIS layers. Such layers are settlements, settlement centers, forests, housings, rivers, lakes, roads, and boundary maps of the study region. These GIS layers as quadrangles were generated from the base maps of the standard topographic quadrangles at the scale of 1:100,000 which were originally produced by the HGK (HGK 2013). All these maps and GIS layers were used for geo-referencing as well as overlaying and comparing with the other resultant maps from the ASTER elevation data and the Lansat-7 ETM+ imagery.

\section{Higher-resolution ground data}

Two hundred ground control points (GCPs) as reference points were collected by the field work activities using a hand-held GPS with horizontal coordinates and attributes with spatial horizontal expected error of $\pm 3 \mathrm{~m}$ in addition to both higher-resolution images of the Google Earth and the topographic maps (HGK 2013). These data were used for geo-referencing and ground truth, as well as for accuracy assessment of the image classification (Congalton 1991; Congalton and Green 1999; Lillesand and Kiefer 2004; Jensen 2005). Most of the GCPs were visible on the higher-resolution imagery, such as intersections of the major rivers, roads, and sharp corners of buildings as well as distinctive points.

\section{Method}

\section{Processing the ASTER DEM data}

A methodology to process multi-scaled different data sources as spatial data (coordinate information) in addition to non-spatial data (attribute information) of the study region was created for the flood hazard risk interpretation (Fig. 2). The methodology used to analyze the digital terrain (Wilson and Gallant 2000; El Sheimy et al. 2005) of the study region is depicted in Fig. 2. To pre-process the data, the Landsat-7 ETM+ multi-spectral image data set and the ASTER elevation data were coregistered using the reference system for satellite imagery in GeoTIF format with grid size $30 \mathrm{~m}$, the WGS 84 datum, and the UTM projection coordinate system with zone number $35 \mathrm{~N}$. Then, the entire study region was extracted using Extract by Mask tool of the Extraction Menu in the ArcGIS system (ArcGIS 2013) and imported to the Idrisi Selva system (IDRISI 2013) for later processes, such as classification and analysis of the elevation and image data.

The ASTER DEM with spatial resolution of $30 \mathrm{~m}$ in geographic coordinates $(\lambda, \varphi$ degrees) obtained from the Internet 
Fig. 2 Methodology: steps of the data processes involved in the flood hazard vulnerability for settlements of the Edirne province

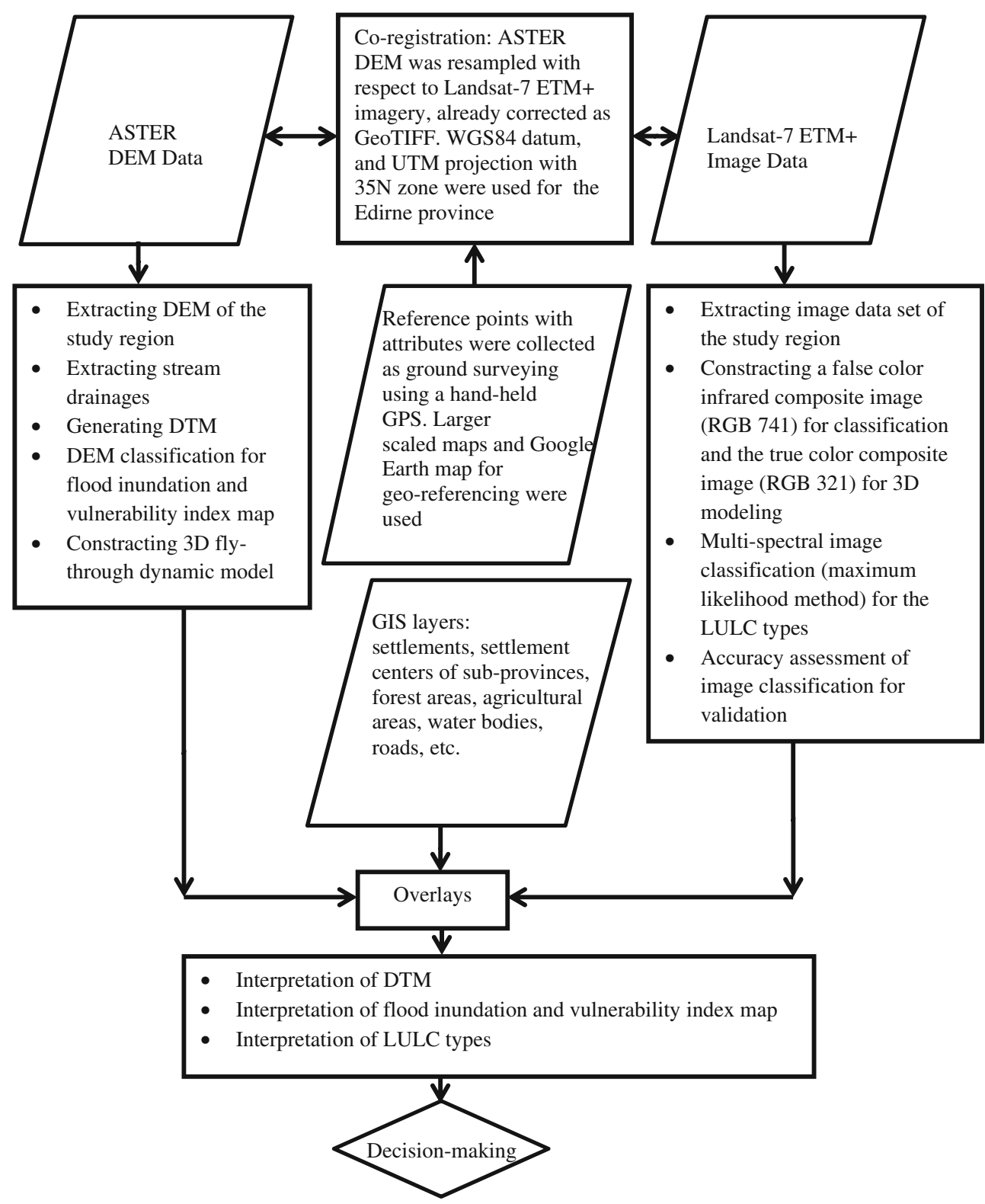

(ASTER GDEM 2013; ERSDAC 2013) was used to classify the elevation data and to extract the stream drainage patterns in the study region.

Before classification, using the Projection tool in the ArcGIS system (ArcGIS 2013), the elevation data were automatically transformed from geographic coordinates $(\lambda, \varphi$ degrees) into the UTM projection system coordinates $(x, y$ meters) with zone number $35 \mathrm{~N}$ and the WGS84 datum. Next, using the Extract by Mask tool of the extraction menu in the ArcGIS system (ArcGIS 2013), the relevant elevation data were extracted according to the boundary of the Edirne province. After that, the extracted elevation data were entered into the Idrisi Selva system for other processing such as the 3D flythrough dynamic image generation. However, the data processes were done using both the ArcGIS and Idrisi systems.
Landforms and stream drainages, coastal flood plains, agricultural plains, plateaus, and mountain areas in the study region were determined from the classification of the ASTER elevation data. Next, the landforms and risk areas were described according to the properties of the stream drainages, and water accumulation areas and were analyzed using the GIS.

The ASTER elevation data were used for extraction of the stream drainages and then were used for analyzing the landforms. Shaded DEM was used to characterize the DTM (Fig. 3 ) to extract geo-information such as slopes and aspects. For the flood risk interpretation, several operations on the elevation data were performed through the ArcGIS (ArcGIS 2013). First, the DTM, a 24-bit color image of the shaded DEM data (Fig. 3), was generated and analyzed by overlaying 


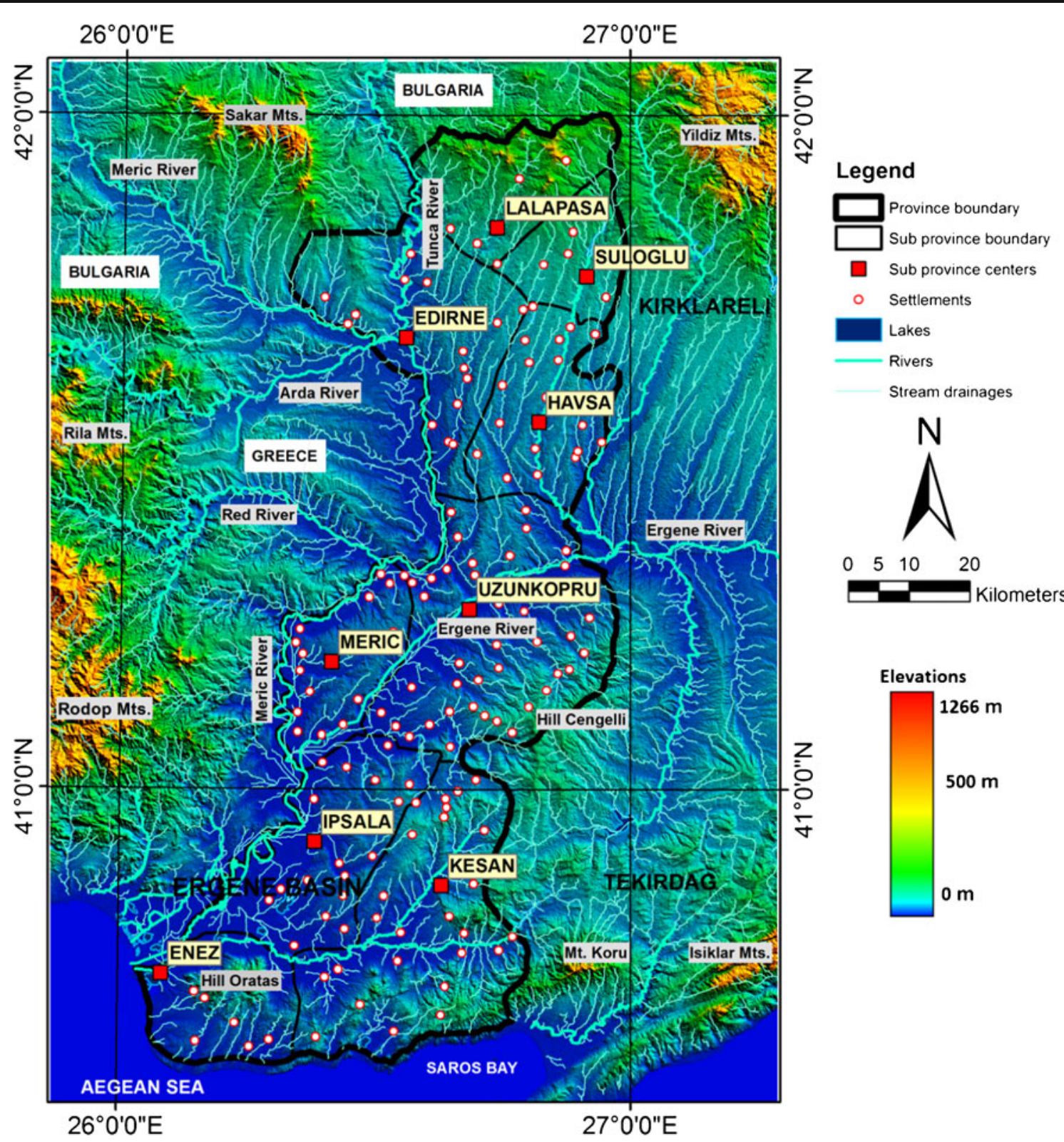

Fig. 3 Digital Terrain Model (DTM) of the Edirne province produced from the ASTER DEM data via the ArcGIS system

settlements, main stream drainages, and their sub-tributaries. Then, the elevation data were classified to identify the main landforms such as valleys, plains, plateaus, hills, and mountains (Fig. 4 and Table 1). The elevation data was also used to generate a perspective view of the 3D fly-through dynamic model via the Idrisi Selva system.

The raster cells with the elevations (1) from 0 to $5 \mathrm{~m}$ were designated as coastal flood risk areas (very high vulnerable areas I); (2) 5 to $10 \mathrm{~m}$ river flood plains I (very highly vulnerable areas II); (3) 10 to $25 \mathrm{~m}$ river flood plains II (highly vulnerable areas); (4) 25 to $50 \mathrm{~m}$ river flood plains III (medium vulnerable areas); (5) 50 to $200 \mathrm{~m}$ plain areas (low vulnerable areas); (6) 200 to $500 \mathrm{~m}$ mountain areas; and (7) 500 to $1266 \mathrm{~m}$ high mountain areas (Table 1) after interactively analyzing the displayed elevation data by the tool of Display Min/Max Contrast Setting in the Idrisi Selva system. For the elevation data classification, sudden and abrupt slope changes in the terrain were considered by interactive analysis. For instance, elevations of locations, where agricultural flat plains finish and mountains slopes start, were considered for classification intervals and/or thresholds. Besides, water flow inflation points (merging river flows), water flow direction (from upper elevation to lower elevation), water flow accumulation areas (valleys and flat plains), slopes, and aspects were considered for vulnerability index analysis.

For the elevation classification, the elevation intervals were subjectively determined (user-determined thresholds) 


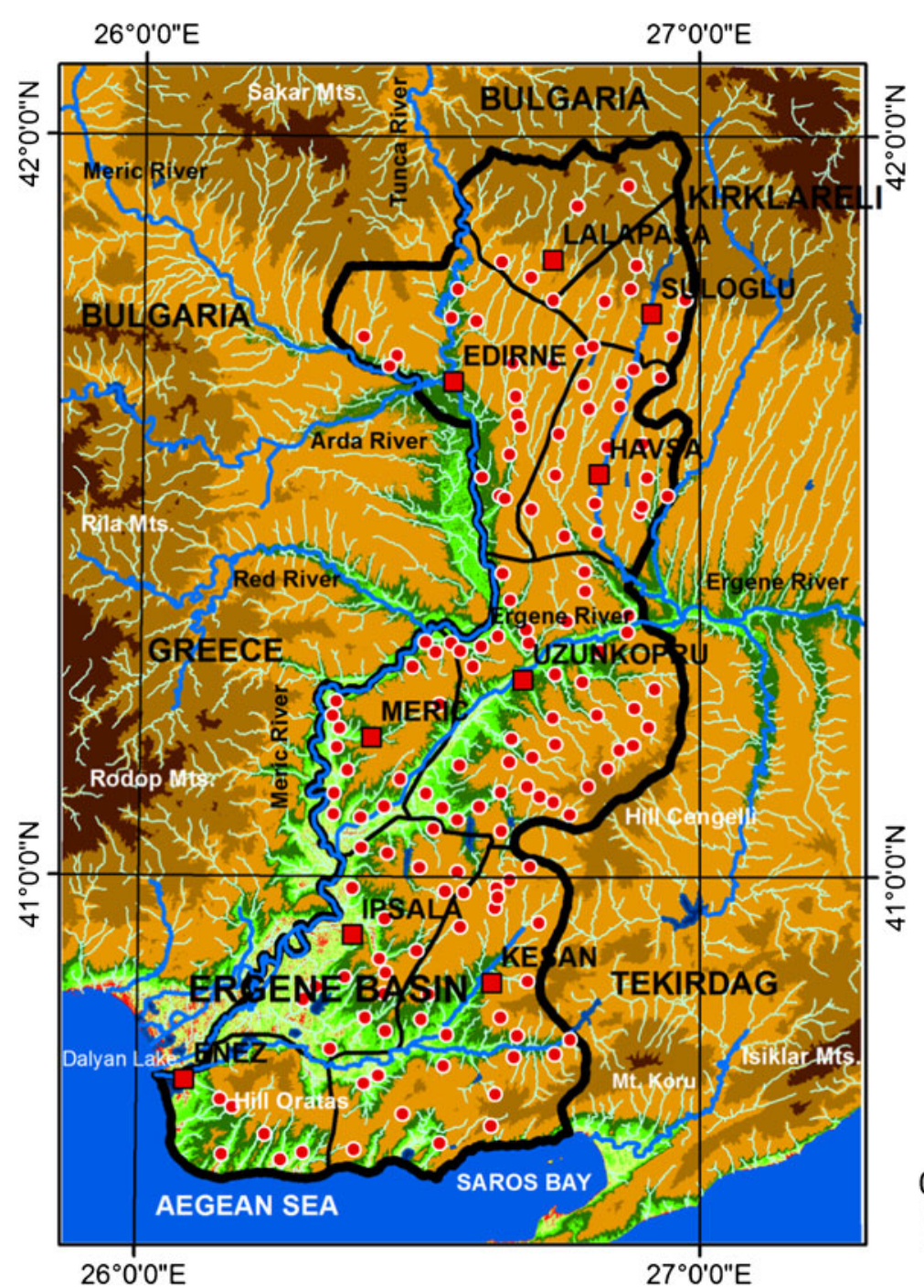

\section{Legend}

$\square \quad$ Sub province centers

- Settlements

Rivers

Province boundary

Sub province boundary

Lakes

Stream drainages

DEM classification and vulnerability level index Meters

Aegean Sea

$0-5 \mathrm{~m}$ Coastal inundation risk areas Very high vulnerable areas I 5 - 10 m River flood plains I Very high vulnerable areas II 10 - 25 m River flood plains II High vulnerable areas

25 -50 m River flood plain III Medium vulnerable areas 50 - 200 m Plain areas

Low vulnerable areas

$200-500 \mathrm{~m}$ Mountain areas

$500-1266 \mathrm{~m}$ High mountain areas

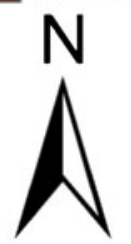

051020

$26^{\circ} 0^{\prime} 0 " \mathrm{E}$

$27^{\circ} 0^{\prime} 0^{\prime \prime} \mathrm{E}$

Fig. 4 The flood inundation and flood hazard vulnerability index map of the Edirne province produced from the ASTER DEM classification via the ArcGIS system

using the DEM visualization function in the ArcGIS system. These elevation classification intervals correspond to sudden color changes, slopes, and aspects, which indicate a sudden change in the terrain surface, representing the borders of the valleys, flat plains, plateaus, hills, and mountains. Therefore, the classified elevation levels and the number of intervals used in the analysis can vary depending on the userdefined thresholds. The elevation intervals were determined by examining the topographic characteristics of the surface of the study area.

After the DEM classification of the landforms and analysis, maps of the mainstream drainage hierarchy, i.e., the Strahler stream orders, were generated from the ASTER elevation data via the Hydrology tool in the ArcGIS system (Mark et al. 1984; O'Callaghan and Mark 1984; Band 1986; Ozdemir and Bird 2009).

For the river flood risk interpretation, the outputs of the hydrological data processing, i.e., the DTM, the elevation classification, and the perspective view of the 3D flythrough dynamic model which indicates landforms, channels of major rivers, hierarchical stream drainages, pour points (junctions of major rivers), and water flow accumulation areas were overlaid with the settlements, roads, rivers, and lakes of the Edirne province.

In the flooding risk interpretation process, five criteria were considered to determine the risk levels for the settlements under threat of flooding: (1) the Strahler stream orders, hierarchies of water-flow inflection of the major river channels via Hydrology tool in the ArcGIS system (ArcGIS 2013); (2) distance from the settlements to the overflow zones of the major river channels; (3) distance from settlements to the major river channels; (4) slopes and aspects of the settlement areas, i.e., flat agricultural plains and valleys; and (5) distance from settlements to water flow accumulation areas and pour points where rivers merge. 
Table 1 Results of the ASTER DEM classification for river flood hazard vulnerability of the Edirne province

\begin{tabular}{|c|c|c|c|c|}
\hline \multicolumn{2}{|c|}{ DEM classification } & \multirow{2}{*}{$\frac{\begin{array}{l}\text { Area } \\
\left(\mathrm{km}^{2}\right)\end{array}}{18}$} & \multirow{2}{*}{$\begin{array}{l}\begin{array}{l}\text { Total } \\
(\%)\end{array} \\
0.01\end{array}$} & \multirow{2}{*}{$\begin{array}{l}\text { Dominant land } \\
\text { cover types }\end{array}$} \\
\hline $0-5 \mathrm{~m}$ & Coastal inundation risk areas & & & \\
\hline $5-10 \mathrm{~m}$ & $\begin{array}{l}\text { Very highly vulnerable areas I } \\
\text { River flood plains I }\end{array}$ & 930 & 15.0 & Agriculture/water body/settlement \\
\hline $10-25 \mathrm{~m}$ & $\begin{array}{l}\text { Very highly vulnerable areas II } \\
\text { River flood plains II }\end{array}$ & 750 & 12.0 & Agriculture/settlement/water body \\
\hline $25-50 \mathrm{~m}$ & $\begin{array}{l}\text { Highly vulnerable areas } \\
\text { River flood plains III }\end{array}$ & 500 & 8.0 & Agriculture/settlement/forest/water \\
\hline & Medium vulnerable areas & & & body \\
\hline $50-200 \mathrm{~m}$ & $\begin{array}{l}\text { Plain areas } \\
\text { Low vulnerable areas }\end{array}$ & 3138 & 50.0 & $\begin{array}{l}\text { Agriculture/settlement/forest/water } \\
\text { body }\end{array}$ \\
\hline $200-500 \mathrm{~m}$ & Mountain areas & 940 & 15.0 & Forest/bare rock \\
\hline $500-1266 \mathrm{~m}$ & High mountain areas & 0 & 0.0 & Forest/bare rock \\
\hline \multicolumn{2}{|c|}{ Total area of Edirne province } & 6276 & 100.0 & \\
\hline
\end{tabular}

Grid size resolution $=30 \mathrm{~m}$; horizontal accuracy $=15 \mathrm{~m}$; vertical accuracy $=8 \mathrm{~m}$. The total area of the whole study region including outside of the Edirne province is $21,260 \mathrm{~km}^{2}$. Elevations of $500-1266 \mathrm{~m}$ indicating high mountains in the whole study area are $14,984 \mathrm{~km}^{2}$

\section{Processing the Landsat-7 ETM+ multi-spectral image data}

The Landsat-7 ETM+ multi-spectral image data set of the study region, corrected and registered as GeoTIFF, with $30 \mathrm{~m}$ resolution, was obtained from the Global Land Cover Facility (GLCF 2013). After having the image data set in the UTM projection coordinate system with zone number $35 \mathrm{~N}$ and the WGS84 datum, the relevant parts were extracted using the Mask operation according to the boundary layer of the study region in the UTM projection coordinate system of the Edirne province obtained from the General Command of Mapping (HGK 2013). The extracted image data set was then imported to the Idrisi Selva system (IDRISI 2013) using the maximum likelihood classification (MLC) for the LULC types (Lillesand and Kiefer 2004; Jensen 2005).

Using the Composite tool, the infrared false color composite image RGB 741 was generated by assigning the seventh band of the Landsat-7 ETM+ image data set to the red (R) channel, the fourth band as an infrared band to the green $(\mathrm{G})$ channel, and the third band to the blue (B) channel in the Idrisi Selva system (IDRISI 2013). The RGB 741 image was used to define the training data set for the MLC. Similarly, the true color composite image RGB 321 was also generated to construct the fly-through dynamic model.

The MLC is a classifier that quantitatively determines both the variance and the covariance of the classes of the pixels in the image bands when grouping the pixels. In this method, an assumption is made such that the pixels in the training classes in the spectral bands are normally distributed. Therefore, the distributions of the classes (grouped pixels of land cover types) can be completely described by the mean vector and the covariance matrix. With these parameters, we can determine the statistical probability of a given pixel value being a member of a specific land cover class (Lillesand and Kiefer 2004; Jensen 2005).

In the Idrisi Selva system, the Maxlike (maximum likelihood classifier) tool was used to execute the MLC of the Landsat-7 ETM+ image data set for the LULC classification based on the information in the set of signature files, generated by the Makesig tool from the training data set, which was defined by on-screen digitizing on the false color composite image RGB 741. The MLC uses the probability density function corresponding to a specific training class signature of the land cover. Pixels are assigned to the most likely class based on a comparison of the posterior probability that it belongs to each of the signatures being considered (IDRISI 2013).

To detect the LULC types (Fig. 5) in this study, the Landsat-7 ETM+ image set of $21,260 \mathrm{~km}^{2}$ including outside of the Edirne province was classified using the MLC method in the Idrisi Selva system (IDRISI 2013). The supervised MLC was performed initially with 12 subclasses using 12 training data set of the land cover. The resultant 12 sub-classes were merged into five classes: settlement, agricultural plain, forest, water bodies, and bare ground (Fig. 5 and Table 2). Therefore, determination and analysis of the LULC from the satellite image set were carried out based on the MLC method. To determine the accuracy of the image classification for validation, a stratified random sampling method were used, making use of the 200 ground control points, collected by the field work activities using a hand-held GPS, with their 


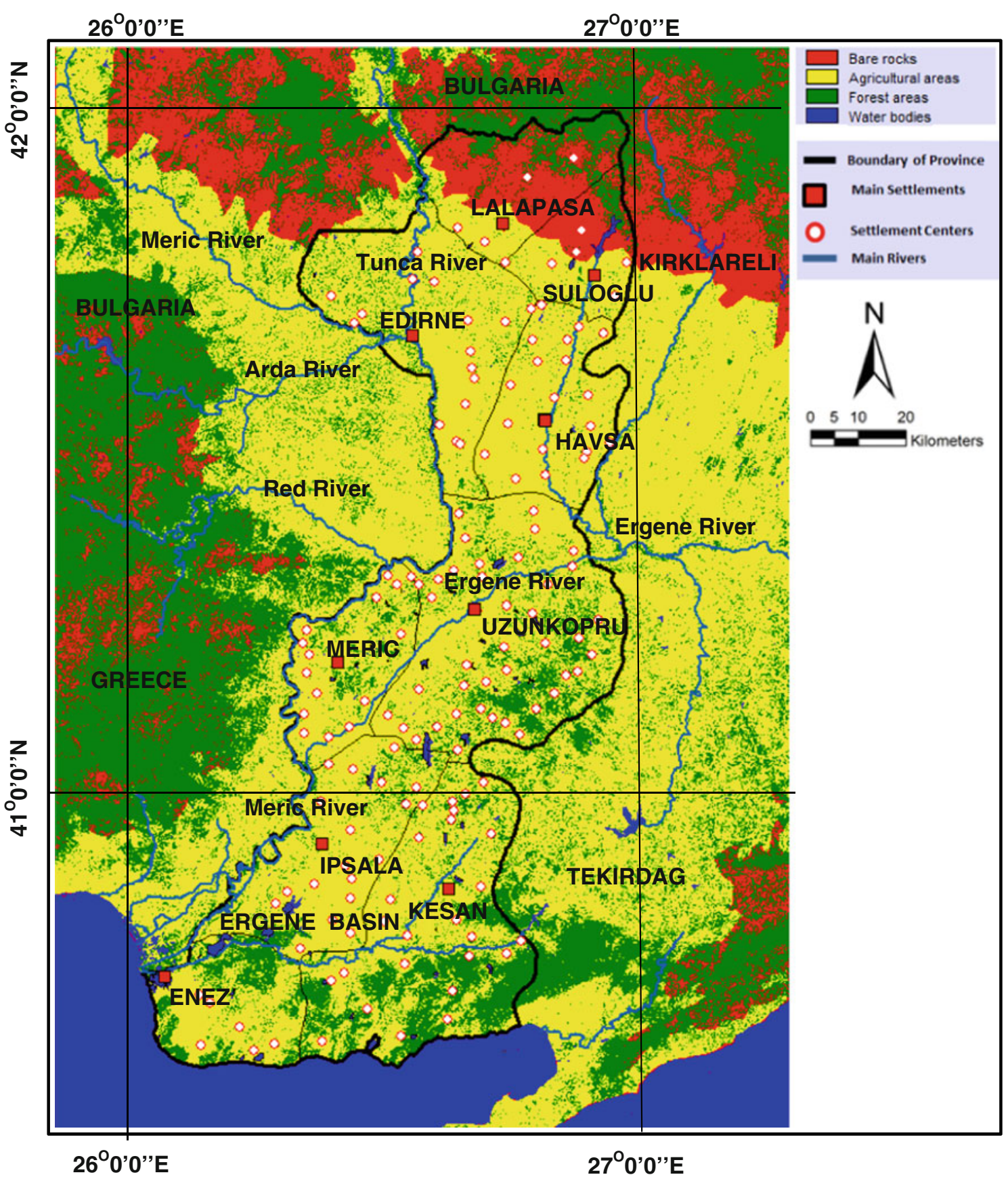

Fig. 5 Land use/land cover (LULC) types of the Edirne province produced from the maximum likelihood classification of the Landsat-7 ETM+ imagery via the Idrisi Selva system

attributes for the classified image (Congalton 1991; Congalton and Green 1999; Lillesand and Kiefer 2004; Jensen 2005; IDRISI 2013).

In terms of the delineation of the river flood risk areas with their LULC types, the procedure of the flood risk interpretation was depicted in Fig. 2. The Landsat-7 ETM+ imagery of the Edirne province was first classified to detect the LULC types. Second, areas most vulnerable to the flood in the study region were determined using the
ASTER elevation data classification. The LULC types were determined by using the MLC method (Lillesand and Kiefer 2004; Jensen 2005; IDRISI 2013). Next, the results of both the image and elevation data classifications were overlaid to interpret the river flood risk areas, river flood plains of Ergene and Meric rivers in our case, with the LULC types. Finally, the flood hazard risk areas were computed, analyzed, and interpreted using both the ArcGIS and the Idrisi Selva systems. 
Table 2 Results of the Landsat-7 ETM+ multi-spectral image classification for LULC of the Edirne province

\begin{tabular}{lccccc}
\hline LULC classification & PA (\%) & UA (\%) & Kappa & Area (km²) & Total (\%) \\
\hline Agricultural areas & 85 & 85 & 85 & 3766 & 60 \\
Forest areas & 95 & 95 & 95 & 1569 & 25 \\
Settlements & 85 & 85 & 85 & 125 & 2 \\
Water bodies (lakes/rivers) & 98 & 98 & 98 & 188 & 3 \\
Bare rocks & 85 & 85 & 85 & 628 & 10 \\
Total area of the Edirne province & & & & 6276 & 100 \\
\hline
\end{tabular}

Landsat-7 ETM+ imagery of July 2000, grid size of $30 \mathrm{~m}$, and horizontal accuracy of $15 \mathrm{~m}$. The total study area including outside of the Edirne province is $21,260 \mathrm{~km}^{2}$

$P A$ producer's accuracy, $U A$ user's accuracy

\section{Results and discussion}

The novelty of this study is that the methodology in Fig. 2 uses integration of remote sensing and geographical information system technologies for decision-making where data come from different sources, types (raster and vector), multi-scales, and accuracies as a data fusion. In addition, quantitative and visual $3 \mathrm{D}$ analyses and interpretation were accomplished for decision-making in terms of flood hazard vulnerability. For interpretation, geomorphological landforms and floodplain topography, in particular, stream drainages and water accumulation areas were overlaid with spatial distribution of settlements in 3D.

In the study, the methodology was used to identify the susceptibility of the settlements and agricultural areas to the river flood hazard. First of all, the DTM in Fig. 3 was generated. Secondly, the flood inundation and flood hazard vulnerability index map in Fig. 4 was generated from the ASTER elevation data classification. Based on the ASTER DEM classification, the findings revealed that (1) coastal flood risk areas with elevations of $0-5 \mathrm{~m}$ as very highly vulnerable areas are $0.01 \%$ of the Edirne province $\left(6276 \mathrm{~km}^{2}\right)$; (2) flood plains I with elevations of 5-10 m, once again, as very highly vulnerable areas cover $15 \%$; (3) river flood plains II with elevations of $10-25 \mathrm{~m}$ as highly vulnerable areas cover $12 \%$; (4) 25 to $50 \mathrm{~m}$ river flood plains III as medium vulnerable areas are $8 \%$; (5) 50 to $200 \mathrm{~m}$ plain areas as low vulnerable areas are $50 \%$; and (6) 200 to $500 \mathrm{~m}$ mountain areas are $15 \%$. There is no high mountain area within the Edirne province (Fig. 4 and Table 1).

Thirdly, the Landsat-7 ETM+ multi-spectral image classification in Fig. 5 was generated. Based on the Landsat-7 ETM+ multi-spectral image classification, the findings revealed that (1) agricultural plain areas are $60 \%$ of the study region $\left(6276 \mathrm{~km}^{2}\right)$; (2) forest areas cover $25 \%$; (3) the settlement areas cover $2 \%$; and (4) water bodies (lakes, dams, and rivers) cover $3 \%$ of the Edirne province (Fig. 5 and Table 2). Fourthly, the fly-through dynamic model in Fig. 6a was generated by draping the true color composite image, RGB 321, onto the ASTER elevation data via the Fly-through tool in Idrisi Selva system. Figure $6 \mathrm{~b}$ was generated by draping the DTM image onto the ASTER DEM elevation data. The overlay of the DEM with the LULC types revealed that all of the flood risk areas are dominantly covered with the agricultural plain areas. Mountain areas are mostly covered with forests. The results are also compared and interpreted with higher-resolution satellite images (Fig. 7) coming from the Google Earth.

The DTM, flood inundation map, fly-through dynamic model, and LULC types as well as enlarged high-resolution satellite images of the study region from the Google Earth (Figs. 3, 4, 5, 6, and 7) indicate that the Meric and Ergene river flood plain areas and the settlements of all over Enez, western Ipsala, western Meric, southwestern Edirne, and northwestern Uzunkopru with their surrounding agricultural plains in decreasing order, respectively, are under threat of flood hazards. From the result, in general, we may say that the most risky areas are the locations where the main subtributaries merge and exacerbate severe flooding. In this study, that part of Edirne where the River Meric merges with its subtributaries, Arda and Tunca, represent the area with the highest risk. The study indicates that the highest flood risk areas are the agricultural areas that lie in the river flood plains of the Meric and Ergene rivers in the Ergene Basin (Figs. 3, 4, 5, 6, and 7 , Table 3).

The elevation classification (Fig. 4) shows that the majority of settlements in Edirne province are located in low-lying agricultural areas with elevations ranging between 50 and $200 \mathrm{~m}$. The river flood plains are primarily located in valleys, particularly the major river channels of the rivers of Meric and Ergene in the Basin Ergene with elevations of 0-50 m. From the results, the flood hazard vulnerability starts with elevation of about $50 \mathrm{~m}$ from the sea level in this study case, and we may say that the flood hazard vulnerability increases as elevations above the sea level are decreasing.

The accuracy of the DEM data depends on the resolution of the grid size, sampling errors and quality of measurements, co-registration, and interpolation techniques. The use of higher-resolution DEMs such as LiDAR and imageries such as GeoEye could produce more accurate and detailed results. 
Fig. 6 a A perspective view of the $3 \mathrm{D}$ fly-through dynamic model of the Edirne province showing flood vulnerability areas. This image was created from the true color composite image $(\mathrm{RGB}=321)$ of the Lansat-7 $\mathrm{ETM}+$ multi-spectral image data set draped on the ASTER DEM data via the Idrisi Selva system. b A perspective view of the 3D flythrough dynamic model of the Edirne province showing flood hazard vulnerability areas, landforms, floodplain topography, main river channels, and water accumulation areas overlaid with settlements. This image was created by draping the DTM image onto the ASTER DEM data via the Idrisi Selva system

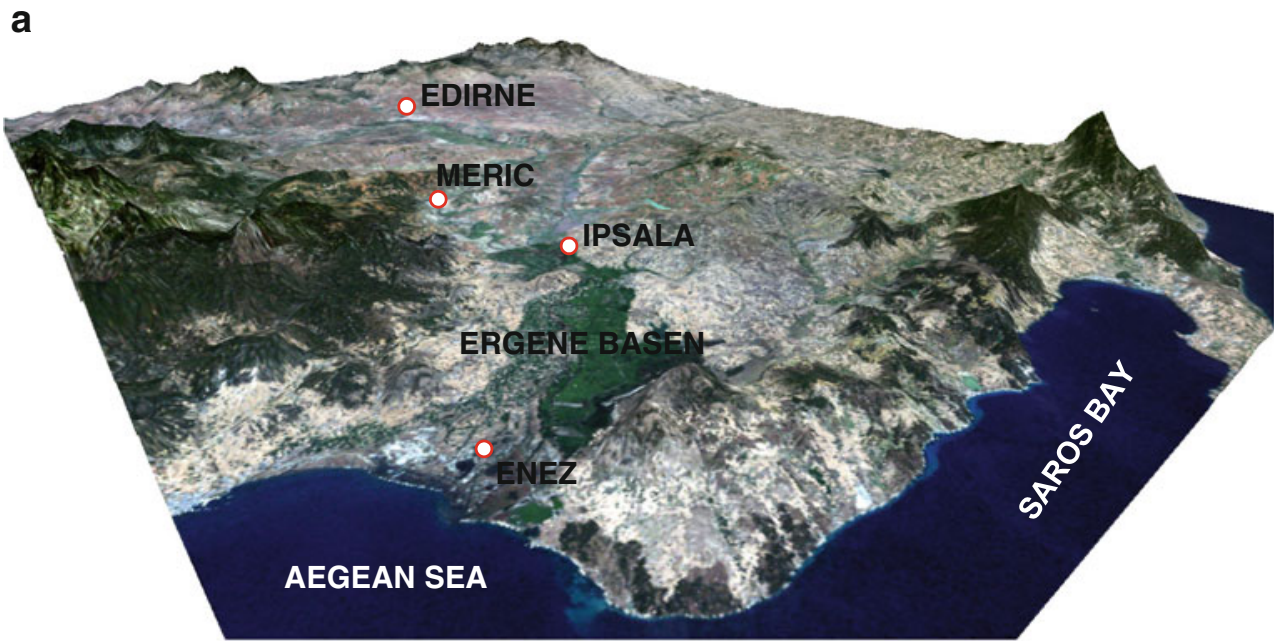

b

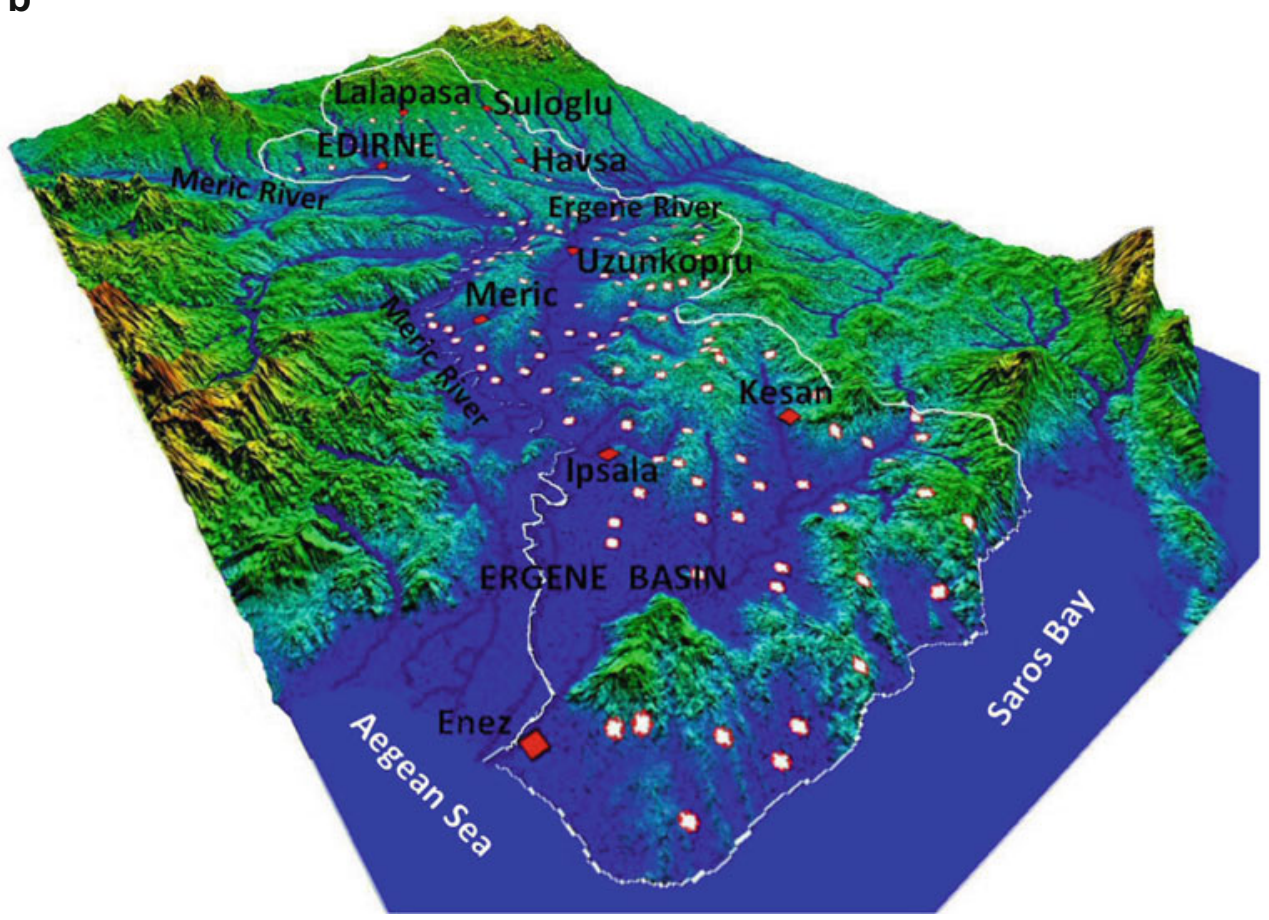

All the results coming from the ASTER elevation data and the Landsat-7 ETM+ multi-spectral image data with other topographic and thematic maps having the different accuracies and scales mentioned above, revealed the Figs. 3, 4, 5, 6, and 7 and Tables 1, 2, and 3 with these accuracies, the risky flood agricultural plains, and the settlements in the study region were interpreted and presented after quantitative and visual analyses.

In the accuracy assessment for this study, first of all, the ASTER elevation data have the spatial resolution of $30 \mathrm{~m}$, with horizontal and vertical accuracies of 15 and $8 \mathrm{~m}$, respectively (San and Suzen 2005; ASTER GDEM 2013; ERSDAC 2013), and the Landsat-7 ETM+ multi-spectral satellite image set have $30 \mathrm{~m}$ spatial resolution, so horizontal accuracy of $15 \mathrm{~m}$ (GLCF 2013), were used in this study. Secondly, 200 reference points as ground control points, also visible on the Landsat-7 ETM+ satellite images by the field work activities using a hand-held GPS with spatial horizontal expected error of $\pm 3 \mathrm{~m}$, were collected and used in the stratified random sampling for the ground truth for the accuracy assessment of the image classification validation (Congalton 1991; Congalton and Green 1999). Finally, the resulting overall classification accuracy of the Landsat-7 ETM+ multi-spectral imagery was $88 \%$, with Kappa values of 0.88 (Table 2). For more detailed information about accuracy assessment of multi-spectral image classifications, see the Classification 

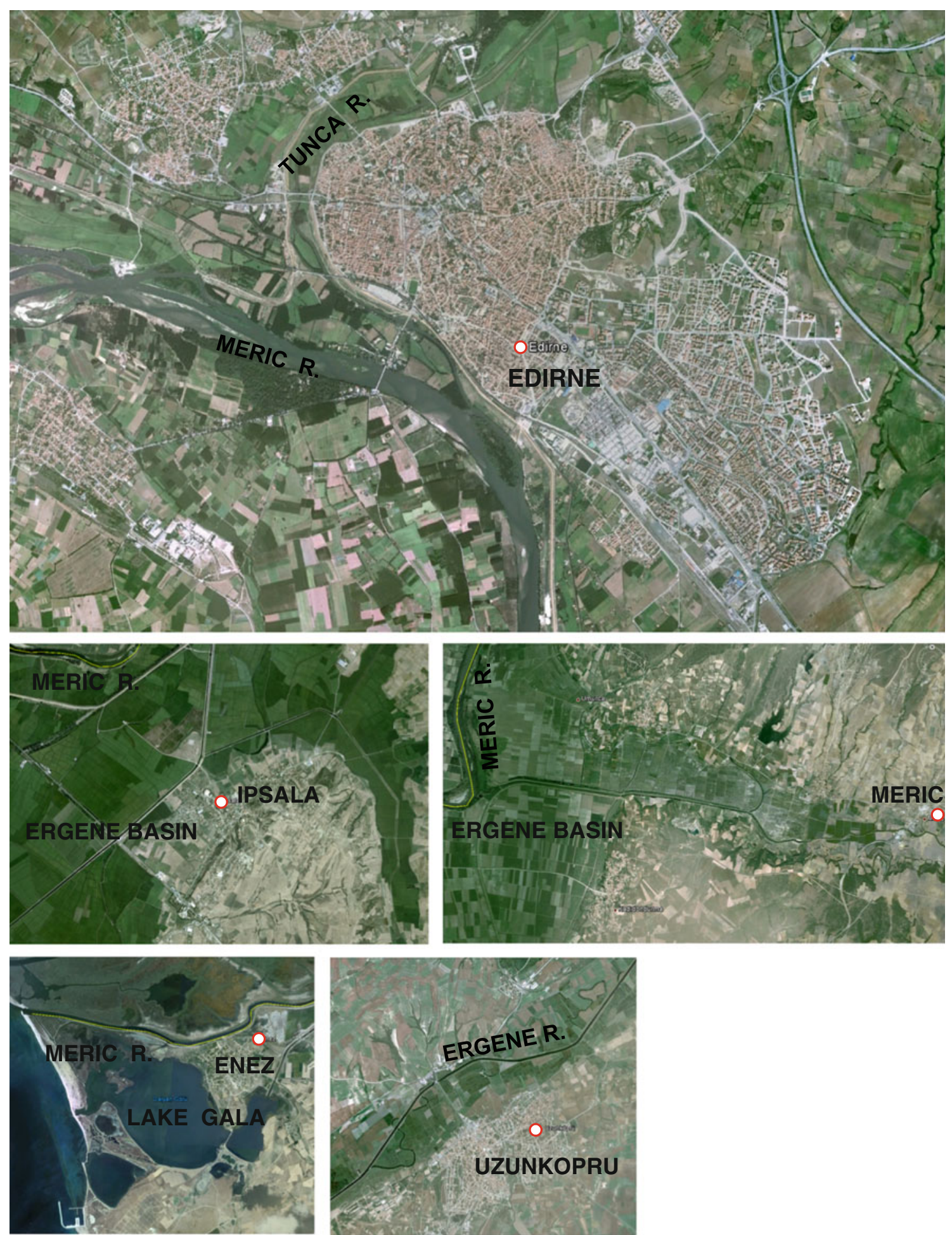

Fig 7 Enlarged satellite images of the river flood hazard risk areas from the Google Earth. These images illustrate the flood hazard risk areas of agricultural floodplains and settlements in the Edirne province affected by the rivers of Meric and Ergene. Source of the satellite images: Google Earth

Accuracy chapter in Lillesand and Kiefer (2004). Classification of water bodies and forests were more accurate than that of the settlements and agricultural land. Overall accuracies, producer's and user's accuracies, and Kappa values for the LULC types were derived from the error matrix. The error matrix includes the columns total, rows total, number of correctly classified cells (diagonal cells), errors of omission (exclusion) and commission (inclusion), an overall accuracy, confidence intervals, and the Kappa statistic for all classes on a per category basis. The overall accuracy of the classification 
Table 3 Results of flood hazard vulnerability for settlements of the Edirne province

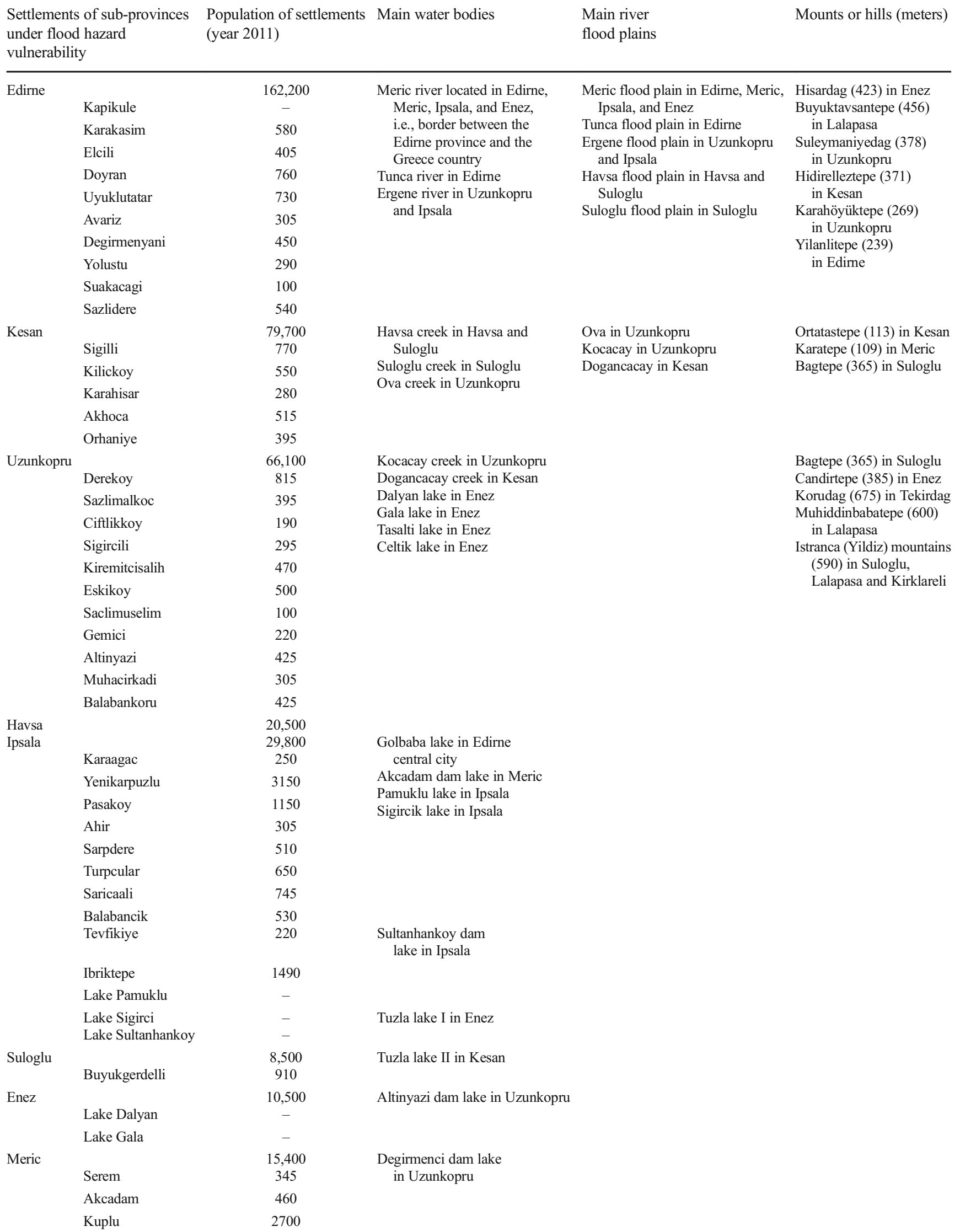


Table 3 (continued)

\begin{tabular}{|c|c|c|c|c|c|}
\hline \multicolumn{2}{|c|}{$\begin{array}{l}\text { Settlements of sub-provinces } \\
\text { under flood hazard } \\
\text { vulnerability }\end{array}$} & \multirow[t]{2}{*}{$\begin{array}{l}\text { Population of settlements } \\
\text { (year 2011) }\end{array}$} & Main water bodies & \multirow[t]{2}{*}{$\begin{array}{l}\text { Main river } \\
\text { flood plains }\end{array}$} & \multirow[t]{2}{*}{ Mounts or hills (meters) } \\
\hline & & & $\begin{array}{l}\text { Suloglu dam lake } \\
\text { in Suloglu }\end{array}$ & & \\
\hline & Subasi & 2000 & & & \\
\hline & Kadidondurma & 800 & $\begin{array}{l}\text { Kocadere dam lake } \\
\text { in Kesan }\end{array}$ & & \\
\hline & Umurca & 350 & & & \\
\hline & Nasuhbey & 300 & $\begin{array}{l}\text { Cavuskoy dam lake } \\
\text { in Enez }\end{array}$ & & \\
\hline & Alibey & 265 & & & \\
\hline & Karayusuflu & 350 & $\begin{array}{l}\text { Umurbey dam lake } \\
\text { in Enez }\end{array}$ & & \\
\hline & Hasirciarnavutkoy & 510 & & & \\
\hline & Rahmanca & 290 & $\begin{array}{l}\text { Dokuzdere dam lake } \\
\text { in Kesan }\end{array}$ & & \\
\hline \multirow[t]{3}{*}{ Lalapasa } & & 7300 & & & \\
\hline & Hamzabeyli & 225 & $\begin{array}{l}\text { Koruklu dam lake } \\
\text { in Kesan }\end{array}$ & & \\
\hline & & & $\begin{array}{l}\text { Mecidiye dam lake } \\
\text { in Kesan }\end{array}$ & & \\
\hline
\end{tabular}

equals to the number of all the correctly classified cells divided by the total number of cells in the imagery (Congalton 1991; Congalton and Green 1999; Lillesand and Kiefer 2004, Jensen 2005; IDRISI 2013).

\section{Conclusions}

In conclusion, identification of the differential vulnerabilities of the entire Edirne flood risk areas to future flood hazards caused by global climate change is urgently required if measures are to be taken in time. To this end, the objective of this study was to contribute to future environmental planning and efficient flood management using a determined methodology to obtain geo-information effectively by analyzing landforms of the study region and to determine the flood hazard risk areas with their LULC types. In addition, a DTM of the study region was generated and interpreted to quantitatively and visually analyze the classification of the landforms. Additionally, the stream drainages were extracted and interpreted to obtain geo-information about the study region. The susceptible river flood plains due to heavy rainfalls and the flood risk areas of the settlements and agricultural areas in the study region were determined by analysis of both the DTM and the stream drainages. Determined landforms and stream drainages are substantially useful for interpreting the river flood risk areas and beneficial for decision-making on environmental planning in the future.

The accuracy of the study greatly relies on the resolution of the grid sizes of the DEM data and imagery, processing errors, quality of measurements, registration, transformation, and map projection. The approach would produce more detailed and accurate results if higher-resolution elevation data (e.g., LiDAR) and image data (e.g., GeoEye) were employed, particularly 5-10 $\mathrm{m}$ resolution. Nevertheless, the results with these data accuracies were promising for determining the flood risk areas of the settlements and agricultural areas.

Acknowledgments The financial support from the Izmir Institute of Technology is gratefully acknowledged.

\section{References}

ArcGIS (2013) Arc GIS 10.2 manual. Redland: ESRI. Available from http://www.esri.com

ASTER GDEM (2013) The Advanced Space-borne Thermal Emission and Reflection Radiometer, Global Digital Elevation Model data. Available from http://gdem.ersdac.jspacesystems.or.jp/

Atalay I (2008) Geography of regions in Turkey (in Turkish). Inkilap Press, Ankara

Band LE (1986) Topographic partition of watersheds with digital elevation models. Water Res 22(1):15-124 
Baykan AR (2004) River basins in the environmental atlas of Turkey (in Turkish). Available from http://www.cedgm.gov.tr/CED/Files/ cevreatlas $\% \mathrm{C} 4 \% \mathrm{~B} 1 / \mathrm{atlas}$ metni.pdf

Brivio PA, Colombo R, Maggi M, Tomasoni R (2002) Integration of remote sensing data and GIS for accurate mapping of flooded areas. Int J Remote Sens 23(3):429-441

Congalton RG (1991) A review of assessing the accuracy of classifications of remotely sensed data. Remote Sens Environ 37:35-46

Congalton RG, Green K (1999) Assessing the accuracy of remotely sensed data: principles and practices. Lewis, CRC, New York

Edirne Governorship, Turkey (2013) Available from http://www.Edirne. gov.tr/

El Sheimy N, Valeo C, Habib A (2005) Digital terrain modeling: acquisition, manipulation and applications. Artech House, Boston

ERSDAC (2013) ASTER Global DEM version 2 validation summary report at Earth Remote Sensing Data Analysis Center. Available from http://www.jspacesystems.or.jp/ersdac/GDEM/ ver2Validation/Summary_GDEM2_validation_report_final.pdf

GLCF (2013) The Global Land Cover Facility: Earth Science Data Interface. Available from http://glcfapp.glcf.umd.edu:8080/esdi/

GEODATA (2013) Ministry of Forest and Water, GEODATA (Turkish: Orman ve Su Bakanligi). Available from http://geodata.ormansu. gov.tr/3d/indexv5.aspx

HGK (2013) General command of mapping (Turkish: Harita Genel Komutanligi). Available from http://www.hgk.msb.gov.tr/english/ index.php

Ho LTK, Umitsu M, Yamaguchi Y (2010) Flood hazard mapping by satellite mimages and SRTM DEM in the Vu Gia-Thu Bon alluvial plain, Central Vietnam. International archives on the photogrammetry, remote sensing and space information science, volume XXXVIII, part 8, 275-280, Kyoto, Japan

Hoque R, Nakayama D, Matsuyama H, Matsumoto J (2011) Flood monitoring, mapping and assessing capabilities using RADARSAT remote sensing, GIS and ground data for Bangladesh. Nat Hazards 57: $525-548$

IDRISI (2013) Idrisi Selva 16.03 manual. Worcester: Clark labs, Clark University. Available from http://www.clarklabs.org/

Jensen JR (2005) Introductory digital image processing: a remote sensing perspective, 2nd edn. Prentice-Hall, Englewood Cliffs

Kandilioti G, Makropoulos C (2012) Preliminary flood risk assessment: the case of Athens. Nat Hazards 61:441-468
Kim J, Kuwahara Y, Kumar M (2011) A DEM-based evaluation of potential flood risk to enhance decision suppoprt system for safe evacuation. Nat Hazards 59:1561-1572

Lillesand TM, Kiefer RW (2004) Remote sensing and image interpretation. Wiley, New York

Mark DM, Dozier J, Frew J (1984) Automated basin delineation from digital elevation data. Geo-Processing 2:299-311

Meyer V, Scheuer S, Haase D (2009) A multi-criteria approach for flood risk mapping exemplified at the Mulde river, Germany. Nat Hazards 48:17-39

MGM (2013) Turkish state meteorological service-natural flood disaster (Turkish: Meteoroloji Genel Mudurlugu). Available from http://www.mgm.gov.tr/arastirma/dogal-afetler.aspx?s= taskinlar

O'Callaghan JF, Mark DM (1984) The extraction of drainage networks from digital elevation data. Computer Vision Graph Image Processing 28:328-344

Ozdemir H, Bird D (2009) Evaluation of morphometric parameters of drainage networks derived from topographic maps and DEM in point of floods. Environ Geol 56:1405-1415

San BT, Suzen ML (2005) Digital elevation model (DEM) generation and accuracy assessment from ASTER stereo data. Int J Remote Sens 26(22):5013-5027

Sanyal J, Lu XX (2004) Application of remote sensing in flood management with special reference to monsoon Asia: a review. Nat Hazards 33:283-301

Schanze J, Zeman E, Marsalek J (eds) (2006) Flood risk management: hazards, vulnerability and mitigation measures, Proceedings of the NATO advanced research workshop on flood risk management, vol 67. Czech Republic, Ostrov

TUIK (2013) Turkish Statistical Institute (Turkish: Turkiye Istatistik Kurumu). Available from http://www.turkstat.gov.tr

Van der Sande CJ, de Jong SM, de Roo APJ (2003) A segmentation and classification approach of IKONOS-2 imagery for land cover mapping to assist flood risk and flood damage assessment. International Journal of Applied Earth Observation and Geoinformation 4(3): 217-229

Wang Y, Colby JD, Mulcahy KA (2002) An efficient method for mapping flood extent in a coastal floodplain using Landsat TM and DEM data. Int J Remote Sens 23(18):3681-3696

Wilson JP, Gallant JC (2000) Terrain analysis: principles and applications. Wiley, New York 